\title{
Antihypertensive Therapy in Non-Diabetic Chronic Kidney Disease Associated with Proteinuria in Adults
}

\author{
Khawar Maqsood ${ }^{1}$, Adeel Siddiqui ${ }^{2}$, Geoffrey Teehan ${ }^{2 *}$ \\ ${ }^{1}$ Department of Medicine, Baystate Medical Center, Tufts University School of Medicine, Springfield, USA \\ ${ }^{2}$ Department of Nephrology, Lankenau Medical Center, Lankenau Institute for Medical Research, Wynnewood, USA \\ Email: *gteehan@comcast.net
}

Received July 3, 2013; revised August 4, 2013; accepted August 14, 2013

Copyright (c) 2013 Khawar Maqsood et al. This is an open access article distributed under the Creative Commons Attribution License, which permits unrestricted use, distribution, and reproduction in any medium, provided the original work is properly cited.

\begin{abstract}
Controlling blood pressure and reducing proteinuria are common goals in Chronic Kidney Disease associated with hypertension and proteinuria and lead to fewer cardiovascular outcomes. This review summarizes the available literature.
\end{abstract}

Keywords: Hypertension; Proteinuria; Chronic Kidney Disease

\section{Introduction}

Proteinuria is a risk factor for progression of chronic kidney disease (CKD) and is associated with adverse cardiovascular outcomes. Controlling blood pressure particularly with strongly anti-proteinuric agents slows the progression of chronic kidney disease (CKD) and delays/ prevents cardiovascular outcomes. Angiotensin converting enzyme inhibitors (ACE-I) and angiotensin receptor antagonists (ARBs) have a blood pressure-independent antiproteinuric effect and are considered first line agents in this scenario [1]. This review will apprise the literature to date on antihypertensive agents studied in non-diabetic proteinuric kidney disease. Table 1 summarizes these trials.

\section{ACE Inhibitors}

Captopril was the first ACE-I approved by Food and Drug Administration (FDA) in 1981 followed by enalapril which was marketed two years later. Since then at least twelve other ACE-I have been marketed. Multiple trials have identified a preferential benefit of ACE-I in reducing proteinuria when compared with other antihypertensive drugs. The basis of all these studies was the observation that protein excretion varies directly with the intra-glomerular pressure in animals with structural glomerular disease [2].

Apart from the reduction in intra-glomerular pressure, a variety of other mechanisms may contribute to ACE-I induced reduction in proteinuria. These include:

${ }^{*}$ Corresponding author.
- The hemodynamic effects of ACE inhibition occur rapidly but then become stable, whereas protein excretion progressively decreases over weeks to several months [3].

- Acute administration of angiotensin II increases intraglomerular pressure by causing renal and systemic vasoconstriction but does not reverse the antiproteinuric effect of ACE-I [4].

- Nephrin is a major component of the podocyte slit pore membrane and an important contributor to the glomerular filtration barrier. Angiotensin II reduces the expression of nephrin [5]. In contrast, ACE-I increase expression of nephrin [6].

- ACE-I may contribute to slowing of renal disease by their possible anti fibrotic properties.

- ACE-I related reduction in proteinuria may be associated with a reduction in serum lipid level which may have a beneficial effect on progression of renal disease and systemic atherosclerosis.

Multiple clinical trials have demonstrated a beneficial effect of antihypertensive therapy with renin-angiotensin system (RAS) inhibitors, mostly ACE-I in patients with proteinuric non-diabetic chronic kidney disease (CKD).

Jafar et al studied 1860 patients with CKD in 11 randomized controlled trials (RCT) and the response to ACE-I versus other antihypertensives or placebo [7]. ACE-I use was associated with significant reductions in the rate of progression to end-stage renal disease (ESRD) (7.4\% versus $11.6 \%$, RR 0.69 , 95\% CI 0.51 - 0.94), while that for doubling of the baseline serum creatinine concentration or ESRD was 13.2 versus 20.5 percent (RR $0.70,95 \%$ CI 0.55 - 0.88) independent of blood pressure 
Table 1. Studies of antihypertensive treatment in patients with chronic kidney disease.

\begin{tabular}{|c|c|c|c|c|c|}
\hline Study & Design/Intervention & Effect on GFR & Effect on Proteinuria & $\begin{array}{l}\text { Cardiovascular } \\
\text { outcomes }\end{array}$ & Others \\
\hline Maione et al ${ }^{9}$ & $\begin{array}{c}\text { SR of } 85 \text { RCT. } 21,708 \\
\text { patients. ACE-I, ARBs and } \\
\text { combination therapy in } \\
\text { patients with albuminuria } \\
\text { and other cardiovascular } \\
\text { risk factors. }\end{array}$ & $\begin{array}{l}\text { ACE-I better than } \\
\text { placebo. ARB } \\
\text { better than placebo. } \\
\text { Combination } \\
\text { not better than } \\
\text { monotherapy. }\end{array}$ & $\begin{array}{l}\text { ACE-I better } \\
\text { than placebo. } \\
\text { ARB better } \\
\text { than placebo. } \\
\text { Combination not } \\
\text { better than } \\
\text { monotherapy }\end{array}$ & $\begin{array}{l}\text { Better with } \\
\text { ACE-I versus } \\
\text { placebo only. }\end{array}$ & N/A \\
\hline Benazepril trial $^{10}$ & $\begin{array}{l}583 \text { patients, } 300 \text { patients } \\
\text { received benazepril and } \\
283 \text { received placebo. } \\
\text { Primary end point: doubling } \\
\text { of the baseline Cr or the } \\
\text { need for HD. }\end{array}$ & $\begin{array}{l}\text { Benazepril better } \\
\text { than placebo for } \\
\text { primary end point. }\end{array}$ & $\begin{array}{l}\text { Benazepril therapy } \\
\text { reduced protein } \\
\text { excretion by } 25 \\
\text { percent compared } \\
\text { with placebo. }\end{array}$ & N/A & $\begin{array}{l}\text { Outcomes better } \\
\text { in patients with } \\
\text { glomerular } \\
\text { diseases, diabetic } \\
\text { nephropathy } \\
\text { and those with } \\
\text { baseline urinary } \\
\text { protein excretion } \\
>1 \mathrm{~g} / 24 \mathrm{hr} \text {. }\end{array}$ \\
\hline REIN trial ${ }^{11}$ & $\begin{array}{l}\text { Prospective double-blind } \\
\text { trial, } 352 \text { patients were } \\
\text { classified according to } \\
\text { baseline proteinuria } \\
\bullet \quad 1-3 \mathrm{~g} / 24 \mathrm{~h} \\
\bullet \quad \geq 3 \mathrm{~g} / 24 \mathrm{~h} \\
\text { Randomly assigned to } \\
\text { ramipril or placebo plus } \\
\text { conventional antihypertensive } \\
\text { therapy targeted at achieving } \\
\text { diastolic blood pressure } \\
\text { under } 90 \text { mm Hg. } \\
\text { Primary end point: } \\
\text { rate of GFR decline. }\end{array}$ & $\begin{array}{l}\text { Significantly lower } \\
\text { rate of GFR decline } \\
\text { with ramipril. }\end{array}$ & $\begin{array}{c}\text { In patients with } \\
\text { baseline proteinuria } \\
\text { of } 3 \mathrm{~g} / 24 \text { h or higher, } \\
\text { ramipril was more } \\
\text { Reno protective than } \\
\text { placebo }\end{array}$ & N/A & $\begin{array}{l}\text { More benefits } \\
\text { seen with higher } \\
\text { proteinuria. }\end{array}$ \\
\hline REIN-2 trial $^{13}$ & $\begin{array}{c}\text { Multicenter RCT, } 338 \text { patients } \\
\text { on ramipril were randomized } \\
\text { to intensified control with } \\
\text { felodipine vs conventional } \\
\text { blood pressure control. } \\
\text { Primary outcome was } \\
\text { progression to ESRD. }\end{array}$ & $\begin{array}{l}\text { No benefit seen with } \\
\text { intensified BP control } \\
\text { with felodipine. }\end{array}$ & N/A & N/A & $\begin{array}{l}\text { No Reno protection } \\
\text { in patients with } \\
\text { nondiabetic } \\
\text { proteinuric renal } \\
\text { disease with } \\
\text { dihydropyridine } \\
\text { calcium channel } \\
\text { blockers. }\end{array}$ \\
\hline AASK trial $^{14}$ & $\begin{array}{l}1094 \text { African American } \\
\text { patients with hypertensive } \\
\text { renal disease. Randomly } \\
\text { assigned to ramipril, } \\
\text { amlodipine or metoprolol } \\
\text { Primary outcome: rate } \\
\text { of change in GFR. } \\
\text { Secondary outcome: } \\
\text { composite endpoint of r } \\
\text { eduction in GFR of more } \\
\text { than } 50 \% \text { or more than } \\
25 \text { mL/min per } 1.73 \mathrm{~m}^{2} \text {; } \\
\text { ESRD; or death. }\end{array}$ & $\begin{array}{l}\text { At } 3 \text { years, ramipril } \\
\text { significantly reduced } \\
\text { the relative risk of the } \\
\text { composite endpoint but } \\
\text { not primary outcome. } \\
\text { Beneficial effect of } \\
\text { ramipril was seen in } \\
\text { patients with urine } \\
\text { protein-to-Cr ratio }>0.22 \\
\text { (300 mg protein } / 24 \mathrm{hr} \text { ). }\end{array}$ & N/A & $\begin{array}{l}\text { Ramipril showed } \\
\text { benefit in patients } \\
\text { with urine } \\
\text { protein-to-Cr } \\
\text { ratio }>0.22 \text {. }\end{array}$ & N/A \\
\hline ONTARGET $T^{19}$ & $\begin{array}{l}\text { ACE-I and ARB combination } \\
\text { versus monotherapy. } \\
5623 \text { patients with estimated } \\
\text { GFR less than } 60 \mathrm{~mL} / \text { min per } \\
1.73 \mathrm{~m}^{2} \text { and/or proteinuria. }\end{array}$ & $\begin{array}{c}\text { ACE + ARB resulted } \\
\text { in a small but significant } \\
\text { increase in the incidence } \\
\text { of ESRD and a non } \\
\text { significant increase in } \\
\text { ESRD alone. }\end{array}$ & N/A & $\begin{array}{l}\text { Combination } \\
\text { therapy not better } \\
\text { than monotherapy. }\end{array}$ & $\begin{array}{l}\text { Higher potassium } \\
\text { level with } \\
\text { combination } \\
\text { therapy. }\end{array}$ \\
\hline
\end{tabular}

Abbreviations: SR systematic review, RCT randomized controlled trial, ACE-I angiotensin converting enzyme inhibitor, ARB angiotensin receptor blocker, Cr creatinine, GFR glomerular filtration rate, HD hemodialysis 
control. These benefits of ACE-I correlated with increasing baseline proteinuria but did not apply to those with proteinuria below 500 to $1000 \mathrm{mg} /$ day [8].

Maione et al. conducted a systematic review of 85 RCTs (21,708 subjects) to look at ACE-I, ARBs and combination therapy in patients with microalbuminuria, macroalbuminuria and other cardiovascular risk factors [9]. Neither ACE I, ARB, nor the combination of the two was associated with a significant reduction in the risk of all-cause mortality or fatal cardiac-cerebrovascular events. ACE I, and not ARB, did however reduce the risk of nonfatal cardiovascular events. Development of ESRD disease and progression of microalbuminuria to macroalbuminuria were reduced significantly with ACE-I versus placebo, ARB versus placebo but not with combined therapy with ACE-I and ARB versus monotherapy. Authors concluded that ACE-I and ARB exert independent renal and nonfatal cardiovascular benefits while their effects on mortality and fatal cardiovascular disease are uncertain. Use of combination therapy was not supported by the evidence.

Maschio et al. performed a placebo-controlled RCT involving 583 patients with renal insufficiency (creatinine clearance 30 - $60 \mathrm{ml}$ per minute) in which $300 \mathrm{pa}$ tients received benazepril and 283 received placebo. The primary end point was a doubling of the baseline serum creatinine concentration or the need for dialysis. At three years the risk reduction attributed to benazepril was 53 percent overall (95\% CI, 27\% - 70\%) and was particularly evident in milder kidney disease. The risk reduction was greatest among men; those with glomerular diseases, diabetic nephropathy, or miscellaneous or unknown causes of renal disease; and those with baseline urinary protein excretion above $1 \mathrm{~g}$ per 24 hours. Benazepril was not effective in patients with polycystic kidney disease [10].

The Ramipril Efficacy in Nephropathy (REIN) trial was a RCT in which patients $(\mathrm{N}=352)$ with proteinuric non-diabetic CKD were randomized to ramipril or placebo plus other antihypertensive therapy to attain a diastolic pressure below $90 \mathrm{mmHg}$. It showed similar benefits as the Maschio trial [11]. Stratified by level of daily proteinuria, the primary endpoint was the rate of glomerular filtration rate (GFR) decline. The trial was terminated prematurely in patients excreting more than 3 grams of protein per day because of a significant benefit with ACE-I in ameliorating the rate of decline of renal function ( 0.53 versus $0.88 \mathrm{~mL} / \mathrm{min}$ per month for placebo). Subsequently all patients with proteinuria of $3 \mathrm{~g}$ or more per $24 \mathrm{~h}$ either continued on ramipril or were shifted to ramipril.

A REIN follow-up study compared the rate of decline of renal function and the need for dialysis in patients who continued to receive ramipril (51 patients) and in those originally randomized to conventional antihypertensive therapy plus placebo who were switched to ramipril at the beginning of the observational follow-up (46 patients). At 20 months (and at 44 months for the trial phase and observational follow-up combined), mean rate of GFR decline slowed significantly and end of trial GFRs were significantly higher in the ramipril group (36 vs $24 \mathrm{ml}$ per minute, $\mathrm{P}=0.01$ ). Progression to ESRD was more common in those receiving placebo (35 versus 19, $\mathrm{P}=0.027$ ) [12]. The original and follow-up ramipril studies strongly suggest that patients who particularly benefit are those with prominent proteinuria, but significant benefit was also seen in patients with sub-nephrotic proteinuria (1.0 to $2.9 \mathrm{~g} /$ day).

REIN-2 evaluated lowering blood pressure beyond usual targets in patients with chronic nephropathies using ACE I. Patients receiving ACE I (Ramipril 2.5 - 5 mg/d) with non-diabetic proteinuric CKD (mean baseline GFR $35 \mathrm{~mL} / \mathrm{min}$ and mean proteinuria $2.9 \mathrm{~g} /$ day, $\mathrm{N}=338$ ) were enrolled in this RCT [13]. Subjects were randomly assigned to either conventional (diastolic < $90 \mathrm{~mm} \mathrm{Hg}$; $\mathrm{n}$ = 169) or intensified (systolic/diastolic < 130/80 mm Hg; $\mathrm{n}=169)$ blood-pressure control with Felodipine (5 - 10 $\mathrm{mg} /$ day) added as needed to achieve the intensified blood-pressure level. The primary outcome measure, time to ESRD over 36 months did not differ between the two groups ( $20 \%$ vs $23 \%, \mathrm{P}=0.99$ ). Further blood pressure reduction with Felodipine therefore is not warranted to slow progression to ESRD in this population. These findings are consistent with previous observations showing that dihydropyridine calcium channel blockers fail to provide renoprotection in patients with non-diabetic proteinuric renal disease.

Hypertension and ESRD are more prevalent among African Americans than Caucasians. Monotherapy with a calcium channel blocker or a diuretic may be superior in this population than ACE-I. The African American Study of Kidney Disease and Hypertension (AASK trial) [14] included 1094 African American patients with hypertensive renal disease. Mean GFR was $46 \mathrm{ml} / \mathrm{min}$ (range 20$65 \mathrm{~mL} / \mathrm{min}$ per $1.73 \mathrm{~m}^{2}$ ) and mean protein excretion was about $600 \mathrm{mg} /$ day in men and $400 \mathrm{mg} /$ day in women. Patients were randomly assigned to three different antihypertensive drugs and to two different blood pressure goals. The blood pressure target was a mean arterial pressure of $92 \mathrm{~mm} \mathrm{Hg}$ or less in the intensive-control group (corresponds to lower than the traditional blood-pressure target of 130/80 mm Hg for CKD) and 102 to $107 \mathrm{~mm}$ $\mathrm{Hg}$ in the standard-control group (corresponds to the traditional blood-pressure target of 140/90 mm Hg). Patients were randomly assigned to treatment with an ACE inhibitor (ramipril, 2.5 - $10 \mathrm{mg} /$ day), a calcium channel blocker (amlodipine, 5 - $10 \mathrm{mg} /$ day), or a beta blocker (metoprolol, 50 - $200 \mathrm{mg}$ day); other antihypertensive drugs were added to initial monotherapy to achieve the 
blood pressure goals. The primary outcome was the rate of change in GFR; the main secondary outcome was a composite endpoint of: reduction in GFR of more than 50 percent or more than $25 \mathrm{~mL} / \mathrm{min}$ per $1.73 \mathrm{~m}^{2}$; ESRD; or death.

Although the GFR decline with ramipril and amlodipine therapy were similar at 3 years, ramipril significantly reduced the relative risk of the composite endpoint by 38 percent. Additionally, ramipril was significantly better at slowing GFR decline among those with a urine protein-to creatinine ratio $>0.22$ (approximately equivalent to 300 mg protein in 24 hours). It also showed that sustainedrelease metoprolol has antiproteinuric effects nearly equal to that of ramipril ( $P=0.06$ for the comparison of total change over 4 years) and better than that of amlodipine. Proteinuria increased by $58 \%$ for the amlodipine group and declined by $14 \%$ in the sustained-release metoprolol group between baseline and 6 months $(P<$ 0.001) [14].

After completion of the AASK trial, all of the participants were invited to enroll in a cohort phase during which ramipril was prescribed to everyone. After an additional five years of follow-up progression of nephropathy was significantly slowed but not stopped [15].

\subsection{Use of ACEI/ARB in Advanced CKD}

The pitfalls of using an ACE-I or ARBs in advanced CKD include an initial GFR decline and hyperkalemia, prompting many practitioners to avoid their use. Fan Fan Hou et al. enrolled 422 patients with non-diabetic CKD and randomly assigned them to benazepril or placebo plus other antihypertensive therapy to attain a systolic and diastolic pressure below 130 and $80 \mathrm{mmHg}$, respectively [16]. Patients were divided into two groups based on renal function: Group $1(\mathrm{~N}=141$, Serum Creatinine 1.5 - $3.0 \mathrm{mg} / \mathrm{dL}$; mean GFR $37 \mathrm{ml} / \mathrm{min} / 1.73 \mathrm{~m}^{2}$, mean proteinuria $1.6 \mathrm{~g} / \mathrm{d})$ and Group $2(\mathrm{~N}=281$, Serum Creatinine 3.1 - $5.0 \mathrm{mg} / \mathrm{dL}$, mean GFR $26 \mathrm{ml} / \mathrm{min} / 1.73 \mathrm{~m}^{2}$, mean proteinuria $1.6 \mathrm{~g} / \mathrm{d}$ ).

After an eight-week run-in period in which they received benazepril at $10 \mathrm{mg} /$ day for four weeks 104 patients remained in Group 1 and 224 remained in Group 2. Group 1 subjects then received benazepril (at $10 \mathrm{mg}$ twice daily, since it was deemed unethical to administer placebo), while Group 2 participants were randomly assigned to benazepril (10 mg twice daily) or placebo. Additional antihypertensive therapy was administered to attain blood pressure goals. The primary endpoint was the composite of doubling of the serum creatinine level, ESRD, or death, while secondary endpoints were change in proteinuria and rate of progression of the renal disease.

At a mean follow up of 3.4 years, significantly fewer Group 2 patients (mean GFR of $26 \mathrm{~mL} / \mathrm{min}$ per $1.73 \mathrm{~m}^{2}$ ) treated with benazepril reached the primary endpoint (41 versus 60 percent with placebo), resulting in an overall risk reduction of 43 percent with active therapy. The primary endpoint was reached less often in group 1 patients (22 percent), who had less severe disease and were all treated with benazepril.

In group 2 doubling of the serum creatinine and reaching ESRD occurred in 51 and 40\% fewer patients receiving Benazepril. Fall in proteinuria (52 versus 20 percent) and a slower rate of decline in GFR (6.8 versus 8.8 $\mathrm{mL} / \mathrm{min}$ per $1.73 \mathrm{~m}^{2}$ per year) were also noticed. The benefits with benazepril were independent of blood pressure. Benazepril conferred substantial renal benefits in highly selected patients without diabetes who had advanced renal insufficiency.

The REIN trial confirms the benefit from ACE-I in patients with advanced CKD. As previously mentioned, patients with an initial GFR within the lowest group (11 to $33 \mathrm{~mL} / \mathrm{min} / 1.73 \mathrm{~m}^{2}$ ) had a 20 percent decrease in the rate of decline in GFR and a 33 percent reduction in the incidence of end-stage renal disease.

\subsection{Use of ACE I in Elderly Patients}

The benefits from RAS inhibition in proteinuric CKD patients older than 70 years are largely unknown. Most of the above trials did not include such individuals since older patients with CKD are less likely to have proteinuria. This is confirmed by an analysis of 1190 National Health and Nutrition Examination Survey (NHANES) participants who were over age 70 and had CKD, which was defined as an estimated GFR $<60 \mathrm{~mL} / \mathrm{min}$ per 1.73 $\mathrm{m}^{2}$ or an albumin-to-creatinine ratio $>200 \mathrm{mg} / \mathrm{g}$ of creatinine (approximately $300 \mathrm{mg} /$ day) [17]. This level of proteinuria was present in only 13 percent. There is no evidence of benefit from RAS inhibition in patients with protein excretion below $500 \mathrm{mg} /$ day. It suggests that the great majority of patients over age 70 with CKD would not benefit from RAS inhibition for renal protection and may have harm from a higher rate of side effects. However, this does not fully apply on patients excreting more than $1 \mathrm{~g} /$ day. Treatment of proteinuric individuals over the age of 70 with CKD remains an area for investigation.

\subsection{Combination of ACE Inhibitors and ARBs}

A number of small trials have shown that combination ACE-I and ARB therapy has a greater antiproteinuric effect than either agent alone. A meta-analysis of 14 trials in non-diabetic renal disease found that combination therapy produced a significant $18 \%$ - $25 \%$ greater reduction in proteinuria compared with monotherapy [18]. These trials did not attempt to identify a maximum antiproteinuric dose, did not compare combination therapy to high dose monotherapy, and did not assess renal out- 
comes.

Combination therapy however may have adverse effects in proteinuric CKD. The ONTARGET trial evaluated combination therapy versus monotherapy in a subset of 5623 patients who, at baseline, had reduced renal function (defined as an estimated GFR less than 60 $\mathrm{mL} / \mathrm{min}$ per $1.73 \mathrm{~m}^{2}$ ) and/or proteinuria [19]. Combination therapy resulted in a small but significant increase in the incidence of ESRD or doubling of the serum creatinine ( 0.79 versus 0.56 percent per year), but a nonsignificant increase in ESRD alone (0.34 versus 0.27 percent per year) and caused more hyperkalemia while failing to reduce the risk of cardiovascular disease or death [20].

\section{Other Antihypertensive Drugs}

\subsection{Calcium Channel Blockers}

Numerous studies suggest that the dihydropyridine calcium antagonists (DCAs) and non-dihydropyridine calcium antagonists (NDCAs) have differential antiproteinuric effects. The NDCAs, such as diltiazem and verapamil are generally considered to have significant antiproteinuric effects while DCAs, such as amlodipine and nifedipine either have no effect or cause a small rise in protein excretion [21].

Bakris et al. systematically reviewed 23 studies of NDCA versus DCA and found NDCAs decreased mean proteinuria by 30 percent and DCAs increased proteinuria by 2 percent (95\% CI 10\% - 54\% for the differences between the two drug classes). Similar observations were noted when these agents were used in combination with ACE-I or ARBs: despite similar reductions in blood pressure, the mean change in proteinuria was minus 39 and plus 2 percent for NDCAs and DCAs, respectively. They concluded that NDCA and DCAs lower blood pressure equivalently, but that NDCAs are superior to DCAs in reducing proteinuria in both diabetic and nondiabetic kidney disease [21].

\subsection{Aldosterone Antagonists}

Addition of aldosterone antagonists may provide renal benefits to proteinuric CKD patients over and above the inhibition of RAS blockers by virtue of partially eliminating secondary hyperaldosteronism. Navaneethan et al. performed a meta- analysis of 11 trials in which patients were treated with an ACE-I and/or ARB plus either spironolactone (usually $25 \mathrm{mg} /$ day) or placebo and found a significantly greater reduction in proteinuria in the spironolactone group (weighted mean difference $800 \mathrm{mg} /$ day, 95\% CI 330 - 1270 mg/day). Short-term changes in GFR (less than one year of follow-up) were similar with spironolactone and placebo. However, most of these studies did not first maximize the dose of the ACE-I or ARB, and the aldosterone antagonist was associated with an increased risk of hyperkalemia (relative risk 3.1 in the meta-analysis) [22]. Longer-term data are lacking in this field.

\subsection{Direct Renin Inhibitors}

Aliskiren, being the first oral direct renin inhibitor (DRI) became available in the United States in March 2007. A number of studies have evaluated the blood pressure lowering effect of aliskiren in combination with other antihypertensive drugs [23-26]. Its novel mechanism of action, inhibition of catalytic activity of renin, the most proximal and rate-limiting step in RAS activation, makes it of particular interest. In the AVOID trial, aliskiren plus losartan was associated with a 20 percent greater reduction in proteinuria compared with losartan alone in patients with type-2 diabetes and nephropathy in the absence of a significantly greater effect on blood pressure [27]. However, this effect on proteinuria did not translate into a clinical benefit.

In the ALTITUDE trial, 8600 patients with type-2 diabetes and kidney disease already taking either an ACE-I or ARB were randomly assigned to additional therapy with aliskiren or placebo [28]. The trial was terminated early due to no benefit on the primary cardiovascular and renal outcomes and the preliminary analysis indicated that aliskiren therapy produced a higher rate of adverse events (i.e., non-fatal stroke, hypotension, hyperkalemia) [29]. Other studies also described an increased risk of hyperkalemia when aliskiren is combined with ACE-I or ARB [30]. Thus, aliskiren should not be combined with ACE-I or ARBs.

\subsection{Drugs with Little or No Effect}

Other antihypertensive drugs have little or no effect on protein excretion. As an example, beta blockers, diuretics, and the alpha-1-blockers (such as prazosin) typically have a lesser antiproteinuric effect than RAS inhibitors [31-33]. A meta-analysis showed that ACE-I lowered protein excretion by 40 percent compared with 16 percent for beta blockers and 14 percent for other non-calcium channel blocker antihypertensive drugs [31]. Methyldopa and Guanfacine, have little effect on protein excretion.

\section{Conclusion}

Proteinuria is associated with adverse renal and cardiovascular outcomes. Retarding proteinuria in CKD slows progression of CKD and can limit some cardiovascular outcomes. ACE-I and ARBs are the first line agents in this setting because they have a blood pressure-independent antiproteinuric effect and have shown to improve renal and cardiovascular outcomes. If proteinuria 
is not controlled with ACE-I or ARB, combination therapy is generally discouraged. We recommend the addition of an NDCA such as diltiazem or verapamil, long acting metoprolol or a mineralocorticoid antagonist as the next line agent. Aggressive measures must be taken to improve blood pressure and reduce proteinuria for better renal and cardiovascular outcomes.

\section{REFERENCES}

[1] P. A. Sarafidis, N. Khosla and G. L. Bakris, “Antihypertensive Therapy in the Presence of Proteinuria," American Journal of Kidney Diseases, Vol. 49, No. 1, 2007, pp. 1226. doi:10.1053/j.ajkd.2006.10.014

[2] T. Yoshioka, H. G. Rennke, D. J. Salant, W. M. Deen and I. Ichikawa, "Role of Abnormally High Transmural Pressure in the Permselectivity Defect of Glomerular Capillary Wall: A Study in Early Passive Heymann Nephritis,” Circulation Research, Vol. 61, No. 4, 1987, p. 531. doi:10.1161/01.RES.61.4.531

[3] R. T. Gansevoort, D. de Zeeuw and P. E. de Jong, "Dissociation between the Course of the Hemodynamic and Antiproteinuric Effects of Angiotensin I Converting Enzyme Inhibition,” Kidney International, Vol. 44, No. 3, 1993, pp. 579-584. doi:10.1038/ki.1993.284

[4] J. E. Heeg, P. E. de Jong, G. K. van der Hem and D. de Zeeuw, "Angiotensin II Does Not Acutely Reverse the Reduction of Proteinuria by Long-Term ACE Inhibition," Kidney International, Vol. 40, No. 4, 1991, pp. 734-741. doi:10.1038/ki.1991.268

[5] F. N. Ziyadeh and G. Wolf, "Pathogenesis of the Podocytopathy and Proteinuria in Diabetic Glomerulopathy," Current Diabetes Reviews, Vol. 4, No. 1, 2008, pp. 39-45. doi:10.2174/157339908783502370

[6] R. G. Langham, D. J. Kelly, A. J. Cox, N. M. Thomson, H. Holthöfer, P. Zaoui, N. Pinel, D. J. Cordonnier and R. E. Gilbert, "Proteinuria and the Expression of the Podocyte Slit Diaphragm Protein, Nephrin, in Diabetic Nephropathy: Effects of Angiotensin Converting Enzyme Inhibition,” Diabetologia, Vol. 45, No. 11, 2002, pp. 15721576. doi:10.1007/s00125-002-0946-y

[7] T. H. Jafar, C. H. Schmid, M. Landa, I. Giatras, R. Toto, G. Remuzzi, G. Maschio, B. M. Brenner, A. Kamper, P. Zucchelli, G. Becker, A. Himmelmann, K. Bannister, P. Landais, S. Shahinfar, P. E. de Jong, D. de Zeeuw, J. Lau and A. S. Levey, "Angiotensin-Converting Enzyme Inhibitors and Progression of Nondiabetic Renal Disease. A Meta-Analysis of Patient-Level Data,” Annals of Internal Medicine, Vol. 135, No. 2, 2001, pp. 73-87. doi:10.7326/0003-4819-135-2-200107170-00007

[8] D. M Kent, T. H. Jafar, R. A. Hayward, H. Tighiouart, M. P. Landa, de Jong, D. de Zeeuw, G. Remuzzi, A. L. Kamper and A. S. Levey, "Progression Risk, Urinary Protein Excretion, and Treatment Effects of Angiotensin-Converting Enzyme Inhibitors in Nondiabetic Kidney Disease," Journal of the American Society of Nephrology, Vol. 18, No. 6, 2007, pp. 1959-1965. doi:10.1681/ASN.2006101081

[9] A. Maione, S. D. Navaneethan, G. Graziano, R. Mitchell,
D. Johnson, J. F. Mann, P. Gao, J. C. Craig, G. Tognoni, V. Perkovic, A. Nicolucci, S. De Cosmo, A. Sasso, O. Lamacchia, M. Cignarelli, V. M. Manfreda, G. Gentile and G. F. Strippoli, “Angiotensin-Converting Enzyme Inhibitors, Angiotensin Receptor Blockers and Combined Therapy in Patients with Micro- and Macroalbuminuria and Other Cardiovascular Risk Factors: A Systematic Review of Randomized Controlled Trials,” Nephrology Dialysis Transplantation, Vol. 26, No. 9, 2011, pp. 2827-2847. doi:10.1093/ndt/gfq792

[10] G. Maschio, D. Alberti, G. Janin, F. Locatelli, J. F. Mann, M. Motolese, C. Ponticelli, E. Ritz and P. Zucchelli, "Effect of the Angiotensin-Converting-Enzyme Inhibitor Benazepril on the Progression of Chronic Renal Insufficiency,” The New England Journal of Medicine, Vol. 334, No. 15, 1996, pp. 939-945. doi:10.1056/NEJM199604113341502

[11] The GISEN Group "Randomised Placebo-Controlled Trial of Effect of Ramipril on Decline in glomerular Filtration Rate and Risk of Terminal Renal Failure in Proteinuric, Non-Diabetic Nephropathy,” Lancet, Vol. 349, No. 9069, 1997, pp. 1857-1863. doi:10.1016/S0140-6736(96)11445-8

[12] P. Ruggenenti, A. Perna, G. Gherardi, F. Gaspari, R. Benini and G. Remuzzi, "Renal Function and Requirement for Dialysis in Chronic Nephropathy Patients on LongTerm Ramipril: REIN Follow-Up Trial,” Gruppo Italiano di Studi Epidemiologici in Nefrologia (GISEN). Ramipril Efficacy in Nephropathy. Lancet, Vol. 352, No. 9136, 1998, pp. 1252-1256. doi:10.1016/S0140-6736(98)04433-X

[13] P. Ruggenenti, A. Perna, G. Loriga, M. Ganeva, B. EneIordache, M. Turturro, M. Lesti, E. Perticucci, I. N. Chakarski, D. Leonardis, G. Garini, A. Sessa, C. Basile, M. Alpa, R. Scanziani, G. Sorba, C. Zoccali and G. Remuzzi, "REIN-2 Study Group Blood-Pressure Control for Reno Protection in Patients with Non-Diabetic Chronic Renal Disease (REIN-2): Multi Centre Randomized Controlled Trial,” Lancet, Vol. 365, No. 9463, 2005, pp. 939-946. doi:10.1016/S0140-6736(05)71082-5

[14] J. T. Wright Jr, G. Bakris, T. Greene, L. Y. Agodoa, L. J. Appel, J. Charleston, D. Cheek, J. G. Douglas-Baltimore, J. Gassman, R. Glassock, L. Hebert, K. Jamerson, J. Lewis, R. A. Phillips, R. D. Toto, J. P. Middleton, S. G. Rostand and African American Study of Kidney Disease and Hypertension Study Group, "Effect of Blood Pressure Lowering and Antihypertensive Drug Class on Progression of Hypertensive Kidney Disease: Results from the AASK Trial,” Journal of the American Medical Association, Vol. 288, No. 19, 2002, pp. 2421-2431. doi:10.1001/jama.288.19.2421

[15] L. J. Appel, J. T. Wright Jr., T. Greene, J. W. Kusek, J. B. Lewis, X. Wang, M. S. Lipkowitz, K. C. Norris, G. L. Bakris, M. Rahman, G. Contreras, S. G. Rostand, J. D. Kopple, F. B. Gabbai, G. I. Schulman, J. J. Gassman, J. Charleston and L. Y. Agodoa, "African American Study of Kidney Disease and Hypertension Collaborative Research Group Long-Term Effects of Renin-Angiotensin System-Blocking Therapy and a Low Blood Pressure Goal on Progression of hypertensive Chronic Kidney Disease in African Americans," JAMA Internal Medicine, 
Vol. 168, No. 8, 2008, pp. 832-839.

doi:10.1001/archinte.168.8.832

[16] F. F. Hou, X. Zhang, G. H. Zhang, D. Xie, P Y. Chen, W. R. Zhang, J. P. Jiang, M. Liang, G. B. Wang, Z. R. Liu and R. W. Geng, "Efficacy and Safety of Benazepril for Advanced Chronic Renal Insufficiency,” The New England Journal of Medicine, Vol. 354, No. 2, 2006, pp. 131140. doi:10.1056/NEJMoa053107

[17] A. M. O'Hare, J. S. Kaufman, K. E. Covinsky, C. S. Landefeld, L. V. McFarland and E. B. Larson, "Current Guidelines for Using Angiotensin-Converting Enzyme Inhibitors and Angiotensin II-Receptor Antagonists in Chronic Kidney Disease: Is the evidence Base Relevant to Older Adults?” Annals of Internal Medicine, Vol. 150, No. 10, 2009, pp. 717-724. doi:10.7326/0003-4819-150-10-200905190-00010

[18] R. Kunz, C. Friedrich, M. Wolbers and J. F. Mann, "MetaAnalysis: Effect of Monotherapy and Combination Therapy with Inhibitors of the Renin Angiotensin System on Proteinuria in Renal Disease," Annals of Internal Medicine, Vol. 148, No. 1, 2008, pp. 30-48. doi:10.7326/0003-4819-148-1-200801010-00190

[19] S. W. Tobe, C. M. Clase, P. Gao, M. McQueen, A. Grosshennig, X. Wang, K. K. Teo, S. Yusuf and J. F. Mann, "Cardiovascular and Renal Outcomes with Telmisartan, Ramipril, or Both in People at High Renal Risk: Results from the ONTARGET and TRANSCEND Studies," Circulation, Vol. 123, No. 10, 2011, pp. 1098-1107. doi:10.1161/CIRCULATIONAHA.110.964171

[20] M. MacKinnon, S. Shurraw, A. Akbari, G. A. Knoll, J. Jaffey and H. D. Clark, "Combination Therapy with an Angiotensin Receptor Blocker and an ACE Inhibitor in Proteinuric Renal Disease: A Systematic Review of the Efficacy and Safety Data,” American Journal of Kidney Diseases, Vol. 48, No. 1, 2006, pp. 8-20. doi:10.1053/j.ajkd.2006.04.077

[21] G. L. Bakris, M. R. Weir, M. Secic, B. Campbell and A. Weis-McNulty, "Differential Effects of Calcium Antagonist Subclasses on Markers of Nephropathy Progression," Kidney International, Vol. 65, No. 6, 2004, pp. 19912002. doi:10.1111/j.1523-1755.2004.00620.x

[22] S. D. Navaneethan, S. U. Nigwekar, A. R. Sehgal and G. F. Strippoli, "Aldosterone Antagonists for Preventing the Progression of Chronic Kidney Disease: A Systematic Review and Meta-Analysis," Clinical Journal of the American Society of Nephrology, Vol. 4, No. 3, 2009, pp. 542551. doi:10.2215/CJN.04750908

[23] B. H. Oh, J. Mitchell, J. R. Herron, J. Chung, M. Khan and D. L. Keefe, “Aliskiren, an Oral Renin Inhibitor, Provides Dose-Dependent Efficacy and Sustained 24-Hour Blood Pressure Control in Patients with Hypertension," Journal of the American College of Cardiology, Vol. 49, No. 11, 2007, pp. 1157-1163. doi:10.1016/j.jacc.2006.11.032

[24] J. L. Pool, R. E. Schmieder, M. Azizi, J. C. Aldigier, A.
Januszewicz, W. Zidek, Y. Chiang and A. Satlin, “Aliskiren, an Orally Effective Renin Inhibitor, Provides Antihypertensive Efficacy Alone and in Combination with Valsartan,” American Journal of Hypertension, Vol. 20, No. 1, 2007, pp. 11-20. doi:10.1016/j.amjhyper.2006.06.003

[25] A. Villamil, S. G. Chrysant, D. Calhoun, B. Schober, H. Hsu, L. Matrisciano-Dimichino and J. Zhang, "Renin Inhibition with Aliskiren Provides Additive Antihypertensive Efficacy When Used in Combination with Hydrochlorothiazide," Journal of Hypertension, Vol. 25, No. 1, 2007, pp. 217-226. doi:10.1097/HJH.0b013e3280103a6b

[26] M. M. Shafiq, D. V. Menon and R. G. Victor, "Oral Direct Renin Inhibition: Premise, Promise, and Potential Limitations of a New Antihypertensive Drug," The American Journal of Medicine, Vol. 121, No. 4, 2008, pp. 265-271. doi:10.1016/j.amjmed.2007.11.016

[27] H. H. Parving, F. Persson, J. B. Lewis, E. J. Lewis and N. K. Hollenberg, "AVOID Study Investigators Aliskiren Combined with Losartan in Type 2 Diabetes and Nephropathy," The New England Journal of Medicine, Vol. 358, No. 23, 2008, pp. 2433-2446. doi:10.1056/NEJMoa0708379

[28] H. H. Parving, B. M. Brenner, J. J. McMurray, D. de Zeeuw, S. M. Haffner, S. D. Solomon, N. Chaturvedi, M. Ghadanfar, N. Weissbach, Z. Xiang and J. Armbrecht, "Cardiorenal End Points in a Trial of Aliskiren for Type 2 Diabetes," The New England Journal of Medicine, Vol. 367, 2012, pp. 2204-2213. doi:10.1056/NEJMoa1208799

[29] M. Azizi and J. Ménard, "Renin Inhibitors and Cardiovascular and Renal Protection: An Endless Quest?” Cardiovascular Drugs and Therapy, 2012.

[30] Z. Harel, C. Gilbert, R. Wald, C. Bell, J. Perl, D. Juurlink, J. Beyene and P. S. Shah, "The Effect of Combination Treatment with Aliskiren and Blockers of the Renin-Angiotensin System on Hyperkalemia and Acute Kidney Injury: Systematic Review and Meta-Analysis,” British Medical Journal, Vol. 344, 2012, p. e42. doi:10.1136/bmj.e42

[31] R. T. Gansevoort, W. J. Sluiter, M. H. Hemmelder, D. de Zeeuw and P. E. de Jong, “Antiproteinuric Effect of BloodPressure-Lowering Agents: A Meta-Analysis of Comparative Trials," Nephrology Dialysis Transplantation, Vol. 10, No. 11, 1995, p. 1963.

[32] A. J. Apperloo, D. de Zeeuw, H. E. Sluiter and P. E. de Jong, "Differential Effects of Enalapril and Atenolol on Proteinuria and Renal Hemodynamics in Non-Diabetic Renal Disease,” British Medical Journal, Vol. 303, No. 6806, 1991, p. 821. doi:10.1136/bmj.303.6806.821

[33] M. E. Rosenberg and T. H. Hostetter, "Comparative Effects of Antihypertensives on Proteinuria: AngiotensinConverting Enzyme Inhibitor versus Alpha 1-Antagonist," American Journal of Kidney Diseases, Vol. 18, No. 4, 1991, p. 472. 